\title{
Magnetostratigraphy of the Ouarzazate Basin: Implications for the timing of deformation and mountain building in the High Atlas Mountains of Morocco.
}

Eliseo Tesón , Emilio L. Pueyo , Antonio Teixell , Antonio Barnolas , Jordi Agustí \& Marc Furió

To cite this article: Eliseo Tesón, Emilio L. Pueyo , Antonio Teixell , Antonio Barnolas, Jordi Agustí \& Marc Furió (2010) Magnetostratigraphy of the Ouarzazate Basin: Implications for the timing of deformation and mountain building in the High Atlas Mountains of Morocco., Geodinamica Acta, 23:4, 151-165, DOI: 10.3166/ga.23.151-165

To link to this article: https://doi.org/10.3166/ga.23.151-165

曲 Published online: 13 Apr 2012.

Submit your article to this journal $\pi$

Џ Article views: 68

Q View related articles $\sqsubset$

Citing articles: 9 View citing articles $\llbracket$ 


\title{
Magnetostratigraphy of the Ouarzazate Basin: Implications for the timing of deformation and mountain building in the High Atlas Mountains of Morocco.
}

\author{
Eliseo Tesón ${ }^{1 *}$, Emilio L. Pueyo ${ }^{2}$, Antonio Teixell ${ }^{1}$, \\ Antonio Barnolas ${ }^{2}$, Jordi Agustí ${ }^{3}$, Marc Furió ${ }^{4}$ \\ ${ }^{1}$ Departament de Geologia, Universitat Autònoma de Barcelona, 08193 Bellaterra (Spain) \\ ${ }^{2}$ Dpt. Investigación y Prospectiva Geocientífica, Instituto Geológico y Minero de España, Ríos Rosas 23, 28003 Madrid (Spain) \\ ${ }^{3}$ ICREA, Institute of Human Paleoecology, Universitat Rovira i Virgili, 43005 Tarragona (Spain) \\ ${ }^{4}$ Institut Català de Paleontologia, Universitat Autònoma de Barcelona, 08193 Cerdanyola del Vallès, Barcelona (Spain)
}

Received: 19/05/2009, accepted: 31/03/2010

\begin{abstract}
Two magnetostratigraphic profiles (450 samples) have been carried out to constrain the age of synorogenic formations in the southern foreland of the High Atlas of Morocco. The Amekchoud profile covers the Aït Ouglif and Aït Kandoula alluvial formations that form the bulk of the Ouarzazate basin fill, indicating an age between the upper Langhian and the Messinian (Miocene). Data obtained in the previously unexplored Hadida formation profile covers the oldest terms of the foreland basin succession, but the low quality of the magnetic record only allows proposing a tentative age between the middle Lutetian and an undetermined middle to late Eocene. The correlation of the Amekchoud profile is based on the recognition of the long C5n chron (Tortonian) in the middle part of the section studied and a new vertebrate locality of upper Tortonian age found in the upper part. These results indicate a discontinuous record of foreland basin development in the southern Atlas domain from mid Eocene to late Miocene times, punctuated by an intermediate large hiatus of 20-25 ma (late Eocene to mid Miocene). Thrusting in the Sub-Atlas frontal thrust belt began before the Ait Ouglif and Kandoula formations, probably during the Oligocene, and extends up to recent times. The alternation of periods of deposition with others of no sedimentary record, which does not coincide with specific tectonic events, results probably from the interference of orogenic deformation and the mantle-related thermal uplift events that have been described for the Moroccan Atlas.
\end{abstract}

(C) 2010 Lavoisier SAS. All rights reserved

Keywords: Morocco; High Atlas; magnetostratigraphy; thrusting; uplift; Eocene; Miocene

\section{Introduction}

The High Atlas of Morocco is a high intracontinental mountain chain that has been uplifted by two mechanisms: the first is thrusting with subsequent crustal thickening, and the second is lithospheric buoyancy induced by a thermal anomaly in the mantle. The present-day expression of both processes has been extensively described in the Atlas literature
([1,2,3,4,5] and references therein), but chronologic constraints are scarce and often contradictory. To unravel the relative chronology of both processes it is crucial to understand the history of mountain building and the evolution of relief in this mountain chain.

The timing of the long-wavelength component of uplift caused by the lithospheric thinning has been deduced either

\footnotetext{
* Corresponding author.

Email address: eteson@gmail.com
} 


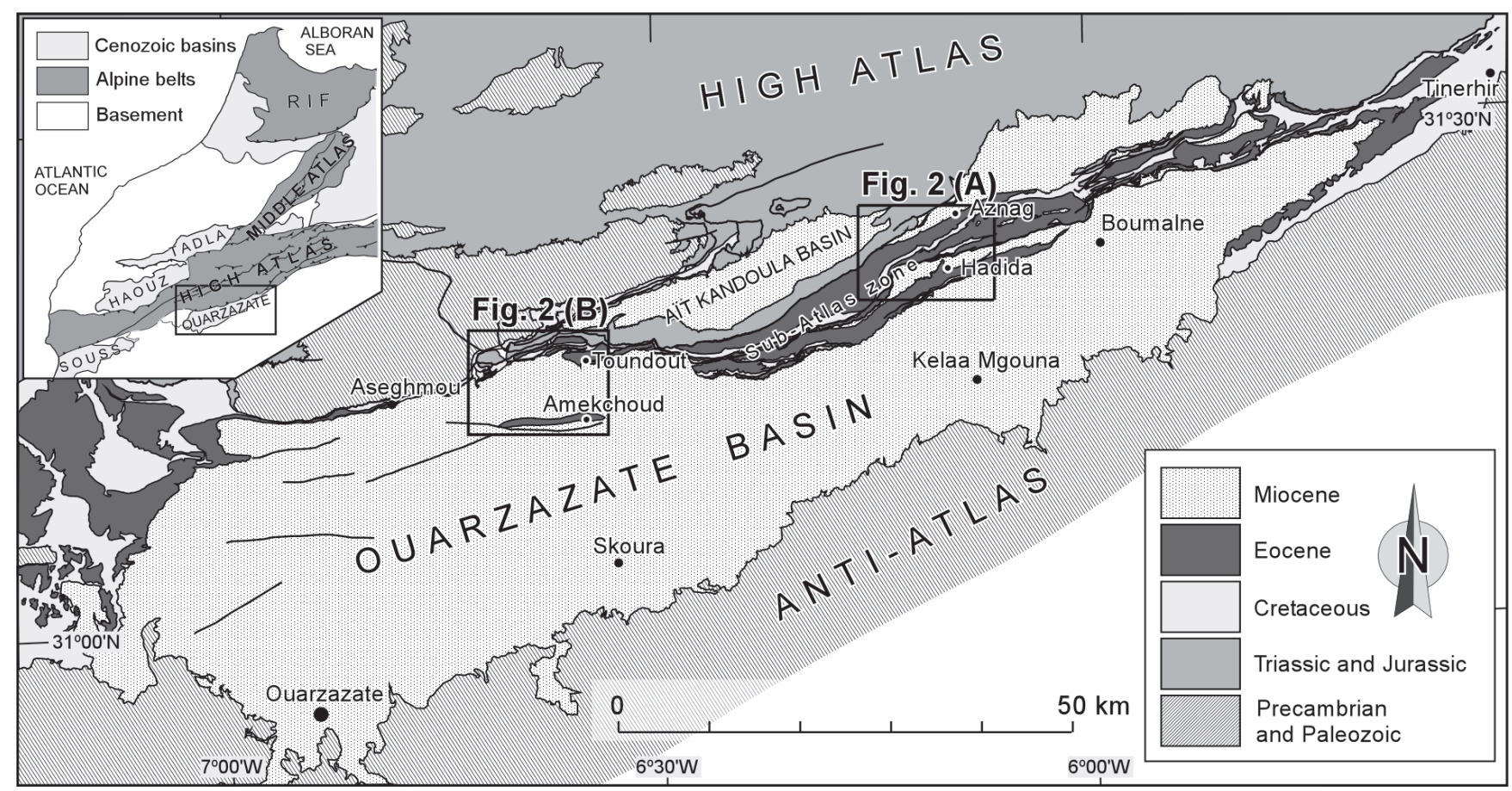

Fig. 1: Geologic sketch map of the Ouarzazate basin south of the central High Atlas of Morocco, indicating the location of the study areas (boxed).

indirectly, i.e., based on the age of related mantle-sourced alkaline magmatic pulses as a first approximation (40-45 ma and past $15 \mathrm{ma}),[2,5]$ or directly from geomorphic/paleoelevation markers (post-Miocene for the current episode [6]).

Much of the dispersion in the published ages of deformation results from poor dating of synorogenic sedimentary formations, which were deposited in continental environments with very scarce fossil remains. The only precise dating available is that by Benammi et al. [17] and Benammi and Jaeger [18] for Neogene sediments in the Ait Kandoula basin (Fig.1), a small thrust-top basin north of the study area. We have undertaken a study of the larger Ouarzazate basin, which contains over $1000 \mathrm{~m}$ of fluvial-alluvial sediments, and have complemented it with a study of the frontal imbricates of the Sub-Atlas Zone that display the oldest terms of the molasse succession. The new ages for the syntectonic sediments obtained in this work constitute the first chronological data for the Ouarzazate basin and allow us to accurately define the timing of thrusting in the vicinity and to extract some general inferences on the chronology of the Atlas orogeny during the past $45 \mathrm{Ma}$.

\section{Geological setting}

The High Atlas is a $100 \mathrm{~km}$ wide, nearly E-W trending thrust and fold belt, localized in the foreland of the Rift-Tell Orogen in the NW African plate (Fig. 1). It was generated by the Cenozoic inversion of a Mesozoic transtensional rift ([1,12,19,20,21], and references therein).

The High Atlas is built by Paleozoic and Mesozoic rocks, essentially Jurassic in age. Cenozoic foreland basin deposits around Atlas Mountains are usually scarce, probably due to the surface uplift generated by the thermal anomaly beneath [2]. Among these, the most complete and best exposed successions are in the Ouarzazate basin, a small elongated basin (145 km long, maximum $35 \mathrm{~km}$ across and $800 \mathrm{~m}$ deep) at the southern side of the High Atlas orogen (Fig. 1).

To the north, the Ouarzazate basin is flanked by a marginal thrust belt called the Sub-Atlas Zone, an imbricate thrust fan constituted by Triassic to Neogene sedimentary rocks, $[7,8,13,22]$. The sedimentary infill of the basin, dominated in outcrop by Neogene alluvial fan to lacustrine sediments and Quaternary pediments and terraces, onlaps to the south the Precambrian rocks of the Anti-Atlas massif.

In the Sub-Atlas thrust belt pre- and syndeformational sediments are well exposed. Above the Mesozoic, the predeformational succession ends with 150 to $400 \mathrm{~m}$-thick bioclastic limestones and marls of late Maastrichtian-Paleocene to mid Lutetian age [23,24], and an undated conformable unit of red shales with gypsum (Hadida formation, up to $700 \mathrm{~m}$ thick) passing laterally to microconglomerates and sandstones (Ait Arbi formation) $[9,22]$. These Cenozoic units are completely affected by the thrust structures, although local unconformities have been described in the base of the limestone formation $[7,25]$. However, the regional distribution of this marine formation across the High and Middle Atlas indicates that sedimentation was not in an orogenic setting but rather in a large epicontinental basin related to the Atlantic margin [26], where only fold ridges of local extent were developed. On the other hand, the Hadida and Aiit Arbi formations, which are never found within the High Atlas hinterland, contain the first significant amounts of detrital material deriving from the orogen, and display thickness variations that altogether allow 

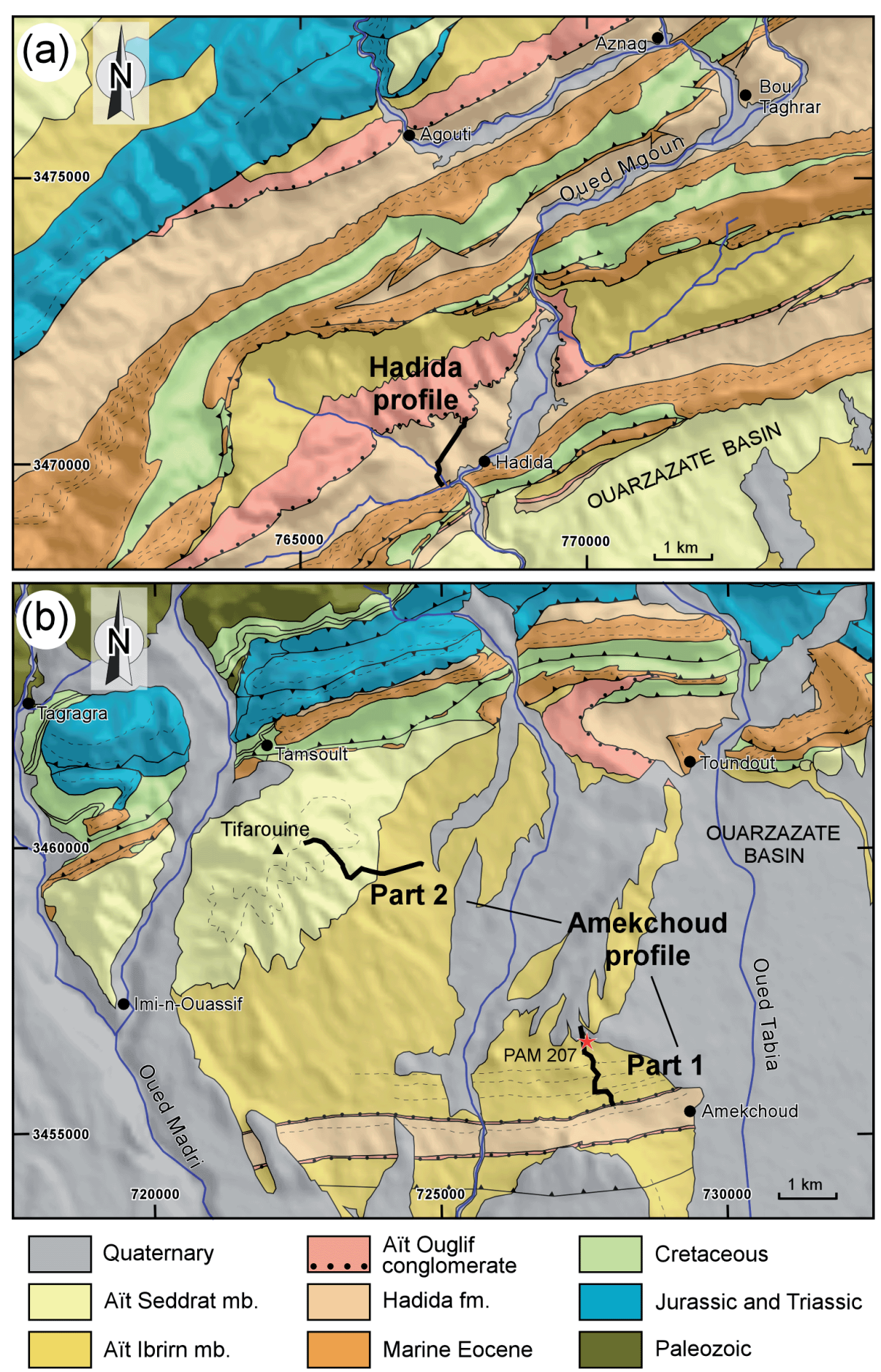

Fig. 2: Detailed geological maps of the Hadida and Amekchoud areas with the situation of magnetostratigraphic profiles. In (a) Aznag village is the paleontological reference for Hadida profile, in (b) PAM 207 marks the fossil locality that constrains the Amekchoud profile. Coordinates correspond to the UTM grid (fuse 29).

to interpret them as the first foreland basin deposits of the Atlas system $[10,12,13]$. Good exposures of the Hadida succession can be found in the frontal imbricates of the Sub-Atlas Zone.

The leading edges of the Sub-Atlas thrust sheets emerged in the proximal Ouarzazate basin margin in post-Eocene times [13]. Post-Eocene sedimentary units are unconformable on fold and thrust structures in the Sub-Atlas belt, and contain evidences of contemporaneous deformation [13]. They include the 30-40m thick Ait Ouglif conglomerate formation [8], and the up to 1000 thick Aït Kandoula formation [9], which dominates the outcrop of the Ouarzazate basin and is constituted by red shales, sandstones, conglomerates and minor lacustrine limestone beds. The age of the Ait Ouglif formation is poorly constrained, having been attributed to the upper Eocene [22], to the lower Miocene [9] or to the Oligocene $[8,11]$. The Aït Kandoula formation has been traditionally attributed to the Mio-Pliocene; a condensed succession of this formation in the Airt Kandoula intramontane basin, $450 \mathrm{~m}$ thick, has been dated by Benammi et al. [17] and Benammi and Jaeger [18] as middle Miocene to lowest Pliocene. The Amekchoud anticline is a km-scale fold within the Ouarzazate basin (Fig. 1) that exposes the Hadida formation in its core and allows the continuous outcrop of a thick (up to $1000 \mathrm{~m}$ ) succession of Ait Ouglif and Ait Kandoula formations, making it suitable for a magnetostratigraphic study.

\section{Stratigraphy and sedimentology}

A profile of the Hadida formation has been sampled for magnetostratigraphy in the Oued Mgoun valley, west of the Hadida village (Sub-Atlas Zone) (Fig. 2a). The profile starts in the upper beds of the Eocene marine succession (31 $\left.{ }^{\circ} 19^{\prime} 50.59^{\prime} \mathrm{N} ; 6^{\circ} 11^{\prime} 19.19^{\prime \prime} \mathrm{W}\right)$, which grade transitionally to the red beds of the Hadida formation, ending at the base of the paraconformable Ait Ouglif conglomerates ( $31^{\circ} 20$ '25.35'N; $6^{\circ} 11$ '04.59'W). The total measured section is of $465 \mathrm{~m}$, and represents the maximum thickness of the Hadida formation preserved in the entire SubAtlas Zone. The lower part of the formation, with thickness of $325 \mathrm{~m}$, corresponds to a red argillaceous succession with interlayered beds of siltstone, sandstone, nodular gypsum and laminated carbonate (Fig. 3a, b). Two main facies types can be recognized in these intercalations; the first one is characterized by basal channelized cross-bedded sandstone followed by rippled fine-grained sandstone and siltstone, and capped by laminated carbonates with gypsum 

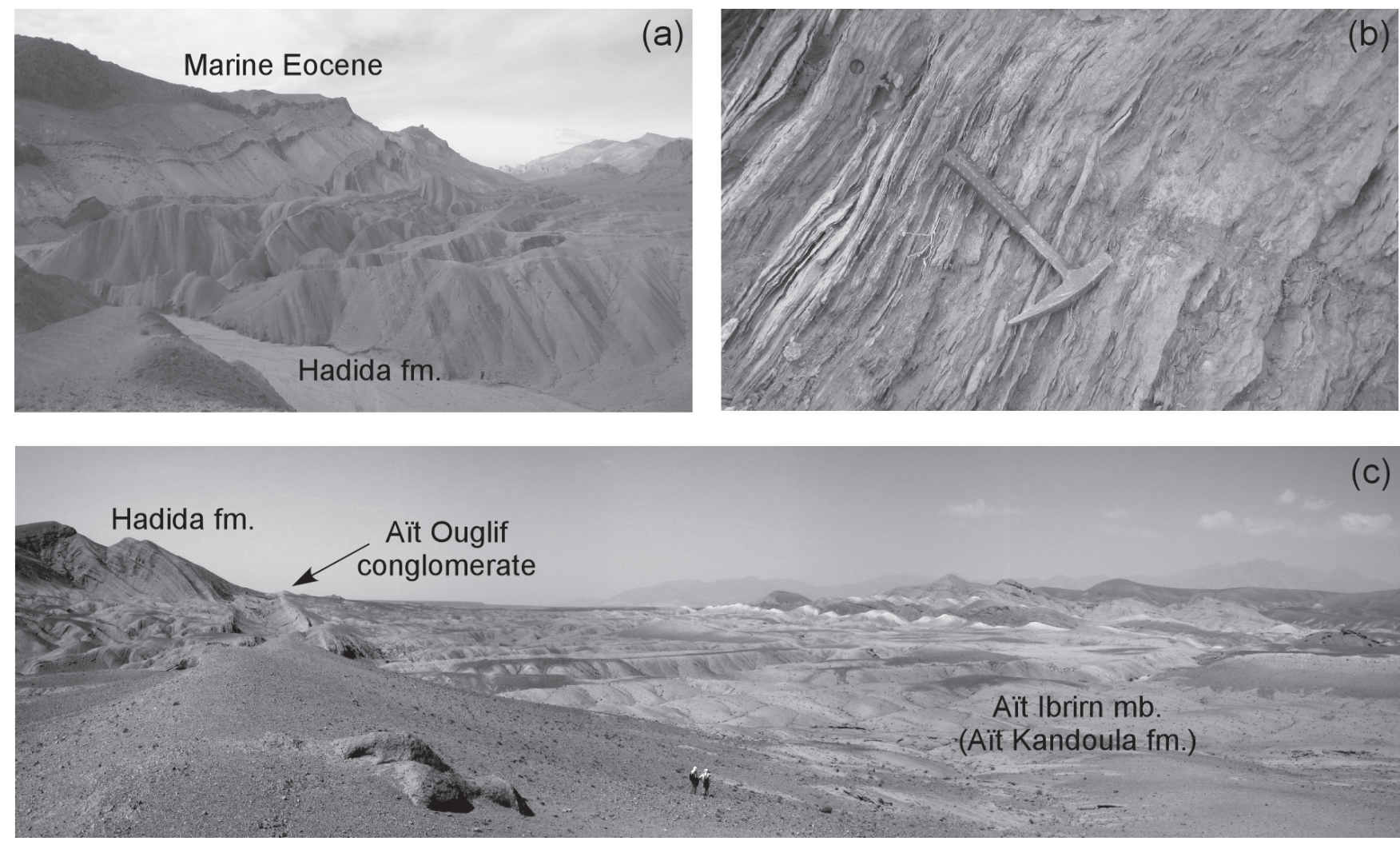

Fig. 3: Field images of main synsedimentary formations analyzed. (a) General view of Hadida formation over conformable Eocene limestones, view of a tributary of the Mgoun river, west of the Hadida village, looking southwest. (b) Detailed view of interlayered beds of siltstone, sandstone, nodular gypsum and laminated carbonate of the lower part of Hadida formation in the valley portrayed in (a). (c) General view of the tertiary succession in Amekchoud area (Ouarzazate basin). View from the Amekchoud village looking west.

crusts on top. The other facies type consists of amalgamated bodies of cross-bedded fine-grained and well-sorted sandstone and gypsarenite interpreted as aeolian deposits. This lower part of the Hadida formation corresponds to the distal part of an aggradational arid alluvial fan system were episodic floods dug ephemeral channels that where partially filled by fluvial sandstones. Laminated carbonates and gypsum crusts related to a playa-lake/coastal sabkha environment developed on the abandoned channels. The sheet-like beds of amalgamated aeolian sandstones could be interpreted as the result of episodic development of sand dune fields.

The upper part of the Hadida formation, $140 \mathrm{~m}$ thick, corresponds to a succession of red microconglomerates, sandstones and bioturbated siltstones and shales that can be assimilated to a fluvial environment. It starts with a thick large-scale cross-bedded sandstone level followed by thinner beds of massive sandstone, usually with cross-bedding in their lower part and occasionally showing hydroplastic deformation, interlayered with bioturbated siltstones and shales. The microconglomerate and sandstone bodies show erosional basal contacts and fining-upward trends from conglomerates to cross-bedded sandstones and, finally, to massive or bioturbated fine-grained sandstones at the top. This upper part of the Hadida Formation displays a general thinning and fining upwards trend in the base, which turns to a thickening and coarsening sequence in the last $40 \mathrm{~m}$.
The Aït Ouglif and the Aït Kandoula formations have been sampled for magnetostratigraphy and paleontology in the northern part of the Ouarzazate basin, west of the Amekchoud village. A profile of the succession has been studied in two separate parts to include the whole series (Fig. 2b). The lower part of the profile $(783 \mathrm{~m})$ starts in the unconformity between the Hadida Fm and the Airt Ouglif Formation, in the core of the Amekchoud anticline $\left(31^{\circ} 12^{\prime} 39.42\right.$ ' $\mathrm{N}$; 6 36'23.05”W) (Fig. 3c), and ends within a shaly succession with thin lacustrine limestone beds below a Quaternary terrace (31 $\left.{ }^{\circ} 13^{\prime} 26.27^{\prime \prime} \mathrm{N} ; 6^{\circ} 36^{\prime} 44.01^{\prime \prime} \mathrm{W}\right)$. The upper part of the profile $(256 \mathrm{~m})$ has been studied in a small creek in the southeast flank of the Tifarouine hill (Fig. 2b). This part of the profile starts in shales and lacustrine beds that are laterally equivalent to the top of the previous $\log \left(31^{\circ} 14^{\prime} 59.77^{\prime \prime} \mathrm{N} ; 6^{\circ} 38^{\prime} 26.19^{\prime \prime} \mathrm{W}\right)$, and ends $50 \mathrm{~m}$ beneath the preserved top of the conglomerates forming the Tifarouine hill $\left(31^{\circ} 15^{\prime} 13.15^{\prime \prime} \mathrm{N} ; 6^{\circ} 39^{\prime} 43.89^{\prime \prime} \mathrm{W}\right)$.

Just below the Ait Ouglif conglomerate, a subaerial erosive surface on top of the Hadida Formation is marked by pedogenetic carbonates. The Airt Ouglif conglomerates, slightly erosive over this pedogenic horizon at the outcrop scale, are represented by a thin succession $(9 \mathrm{~m})$ of amalgamated channels of poorly-sorted conglomerates including pebbles up to 30 $\mathrm{cm}$ in diameter, and of coarse-grained sandstones. The finergrained Ait Kandoula fm overlies conformable the Aït Ouglif conglomerate. It consists of a thick sequence of distal alluvial 


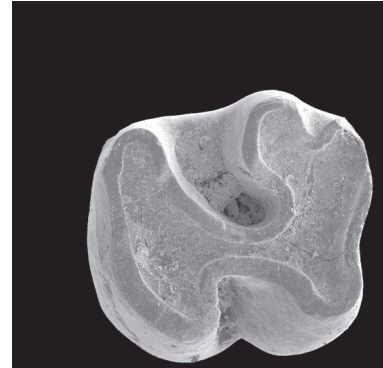

a

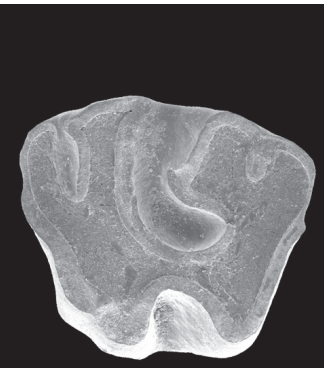

b

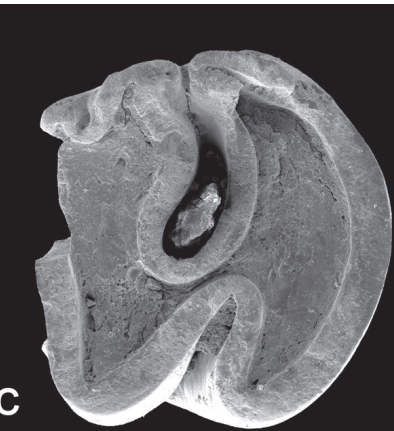

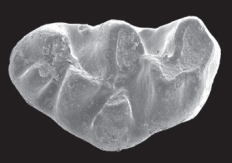

d

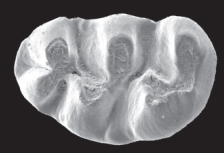

e

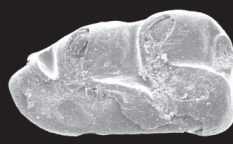

f

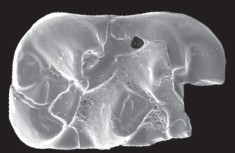

g

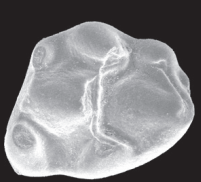

i
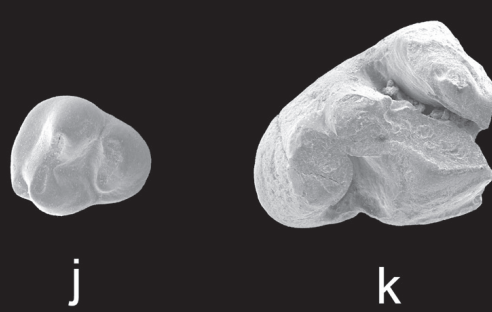

h

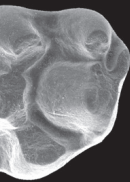

h

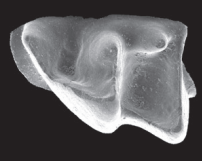

$\mathrm{m}$

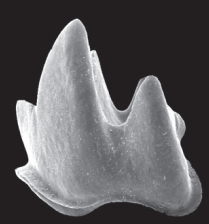

I

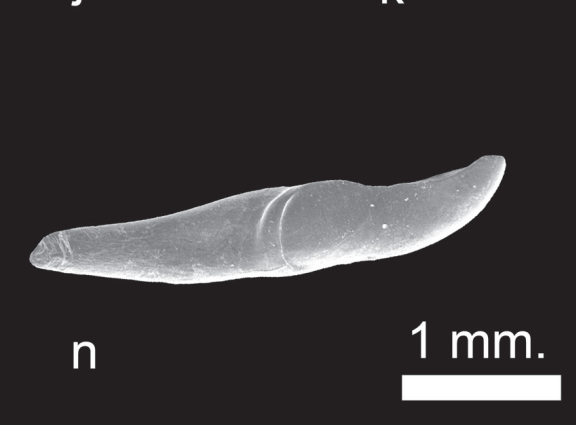

Fig. 4: Fossil molars (M), decidous molars (D) and incisors (I) of the micromammals from Amekchoud section: a: Right upper D4 of Africanomys sp. (PAM 135); b: Right upper D4 of Africanomys sp. (PAM 207); c: Left upper M1-M2 of Africanomys sp. (PAM 207); d: Left upper M1 of Myocricetodon cf. afoudensis (PAM 207); e: Left upper M1 of Myocricetodon cf. afoudensis (PAM 207); f: Left lower M1 of Myocricetodon cf. afoudensis (PAM 207); g: Right lower M1 of Myocricetodon cf. afoudensis (PAM 209); h: Left upper M1 of Paraethomys cf. miocaenicus (PAM 207); i: Left upper M2 of Paraethomys cf. miocaenicus (PAM 207); j: Left lower M3 of Paraethomys cf. miocaenicus (PAM 207); k: Right lower M3 of Zramys cf. hammamai (PAM 207); 1: Left lower M1 of Oligosoricini indet. (PAM 207; labial view); m: Left lower M1 of Oligosoricini indet. (PAM 207; occlusal view); n: Right lower I 1 of Oligosoricini indet. (PAM 207; labial view).

and lacustrine deposits that culminates with the progradation of coarse alluvial fan deposits (Tifarouine hill). Accordingly, two members can be distinguished in this formation: the basal Ait Ibrirn member composed mainly by red shales with sandstone, conglomerate and limestone intercalations, and the Ait Seddrat member, composed predominantly by conglomerates [13].

In the analyzed profile, the Ait Ibrirn member $(\sim 800 \mathrm{~m}$ in thickness), is organized in three main sequences of alluvial sandstones grading to distal alluvial shales with lacustrine carbonates. The lower one is represented by $185 \mathrm{~m}$ of alluvial channels filled by cross-bedded sandstones with conglomerate lags and interbedded with red shales, followed by $210 \mathrm{~m}$ of shales including sporadic alluvial sandstone channels and thin levels of limestone with nodular gypsum. The second sequence is represented by 50 $\mathrm{m}$ of alluvial channels filled by conglomerates and coarse sandstones in a thickening and coarsening upwards macrosequence, followed by $75 \mathrm{~m}$ of shales with sporadic channelized sandstones and conglomerates in the lower part, and lacustrine carbonates, nodular gypsum and gypsarenites in the upper part. The third sequence is represented by 250 $\mathrm{m}$ of shales with conglomerates and sandstones in their lower part and lacustrine carbonates in their upper part.

The Aït Seddrat member reaches a maximum preserved thickness of $264 \mathrm{~m}$ in the study area, of which 214 were suitable for magnetostratigraphic sampling. It overlies the last lacustrine carbonate of the Ait Ibrirn Member and appears as a sudden input of coarse clastic sediments derived from the High Atlas, representing prograding proximal alluvial fan environments with more humidity indicated by hydromorphic soil horizons. The lower part of the Aiit Seddrat Member is represented by conglomerate and sandstone channels with pebbles up to 10 or $30 \mathrm{~cm}$ in diameter. They are interlayered with multicolored shales associated to the development of the hydromorphic soils. Channel thickness increase progressively to the upper part of the section, where the interlayered shaly levels become thinner, redder and bioturbated. The conglomeratic channels are multiepisodic, with sharp basal contacts, often with deep erosive scours but also with large flat basal contacts, occasionally showing internal gravel bars. The conglomerates are 

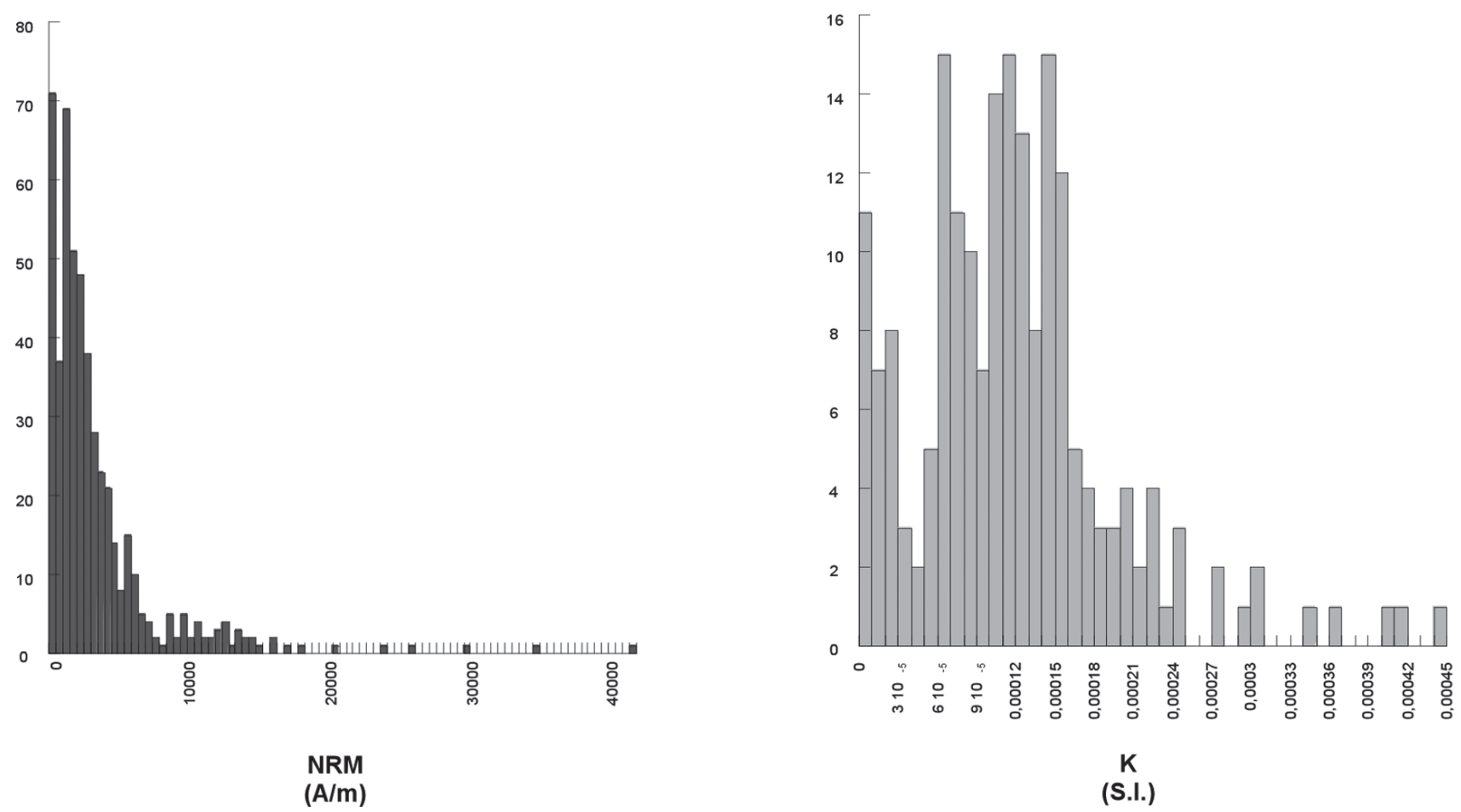

Fig. 5: Initial magnetization (NRM in A/m) and volumetric susceptibility (K in S.I. units) histograms of the study samples from the Hadida and Amekchoud profiles.

clast-supported but poorly sorted, with occasional imbricated pebbles. Pebbles derive dominantly of Jurassic carbonates, and their diameter increases from the base to the top of the section where they can attain up to $120 \mathrm{~cm}$.

\section{Biostratigraphy}

Micropaleontological sampling of the Ait Kandoula formation has been carried out in 4 localities: PAM 135, PAM 141, PAM 207 and PAM 209, situated respectively at 503, 525, 773 and $790 \mathrm{~m}$ from the base of the Amekchoud section. The only significant results come from level PAM 207, located near the top of first part of the profile (Fig. 2b). A small vertebrate sample includes the following species: Oligosoricini indet., Myocricetodon cf. afoudensis Benammi 2001, Zramys cf. hammamai Jaeger 1977 [27], Paraethomys cf. miocaenicus Jaeger et al., 1975 [28], Africanomys sp., Latoglossus sp. (Fig. 4).

Myocricetodon cf. afoudensis is represented by first upper molars with well subdivided anterocone (Fig. 4 d, e, and f). The anterolophule is medially connected to the anterocone and sometimes the longitudinal ridge is interrupted between the paracone and the hypocone. A well developed enterostyle is present in part of the sample. Myocricetodon cf. afoudensis from PAM 207 coincides in size with the sample from the type-locality Afoud 6, from the Aït Kandoula basin [29].

The murid Paraethomys cf. miocaenicus from PAM 207 (Fig. 4 h, i, j) corresponds to a very archaic representative of the genus, best fitting in size and morphology the sample identified with the same name from Amama 2 (Algeria;
Coiffait-Martin [30]). From the five upper molars recovered from this level, no one has developed a T6-T9 connection, while the T9 is well developed in all the teeth. Zramys cf. hammamai is represented by two teeth which exhibit large size and hypsodonty (Fig. 4k).

With respect to Oligosoricini indet. (Fig. 4 1, m, n), the first lower incisor is very small. Only Paenelimnoecus and Suncus are known to reach such reduced dimensions, however, none of both include any species displaying a bended root-crown disposition in their first lower incisors. Such condition is considered to be plesiomorphic within the shrews, and better fits the profile of the archaic Oligosoricini crocidosoricines (sensu Furió et al., 2007 [31]). Considering also that the first lower molar is also peculiar in its talonid by being relatively long compared with the recent white-toothed African shrews, the two soricid teeth recovered are ascribed to an archaic member of the family Crocidosoricinae.

According to its murid content, sample PAM 207 can be placed in an biochronological intermediate position between the Turolian sites of Amama 2 (7.7 ma according to radiometric dating by Coiffait-Martin [30]) and Khendek el Ouaich [27] in Morocco, on the one hand, and those of Argoub Kemellal (Algeria; Coiffait-Martin et al. [32]) and Afoud 5 (> $6.3 \mathrm{ma}$, after magnetostratigraphy [17] in the Aït Kandoula basin, on the other hand. Radiometric dating of a volcanic tuff layer above the fossiliferous level of Kendech el Ouaich has been correlated with the dated volcano at Guilliz (north Morocco) that has an age of 7.58+/- 1.2 Ma according to Choubert et al. [33] radiometric data after Harland et al. [34] correction. In addition, Paraethomys cf. miocaenicus from 

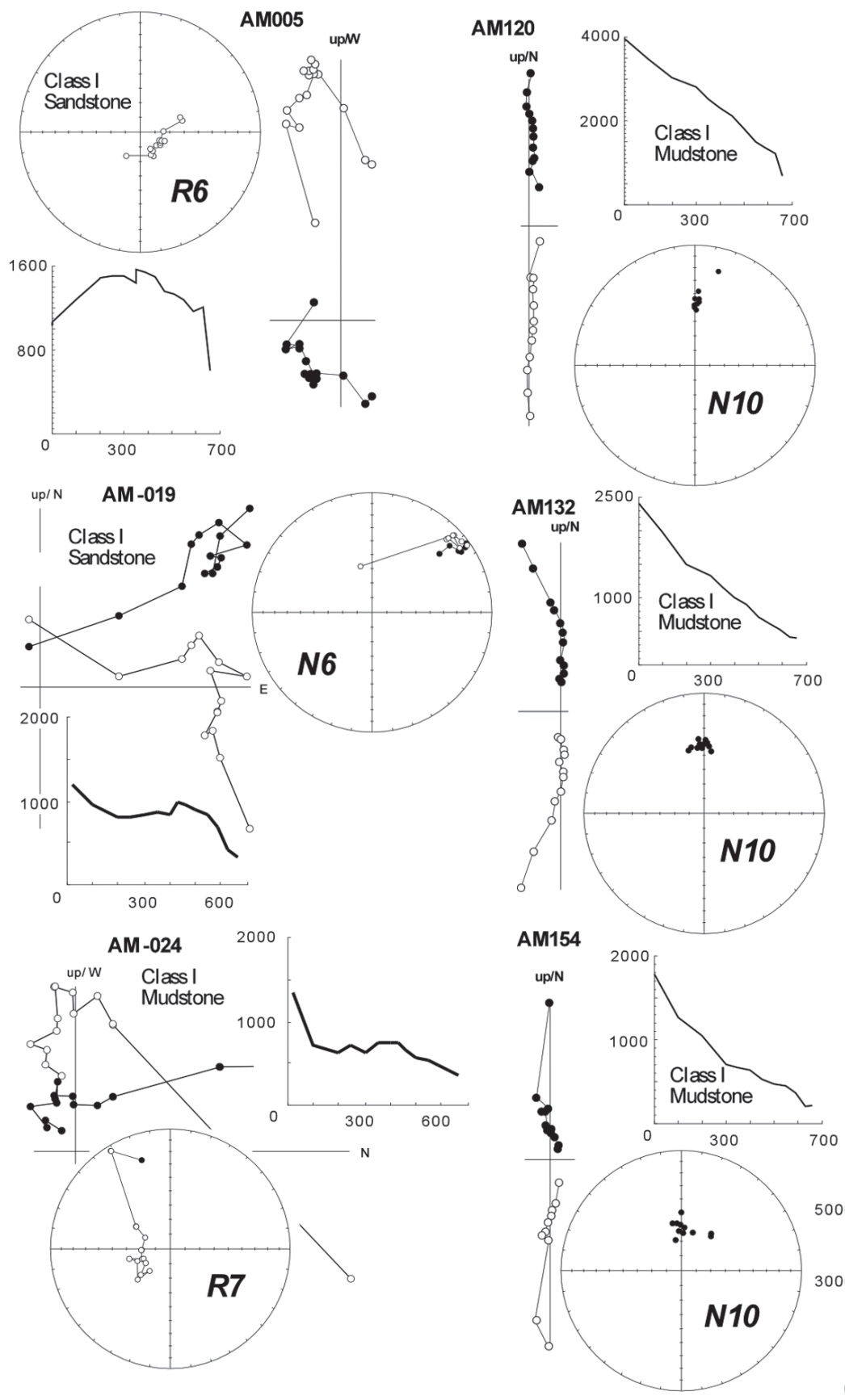
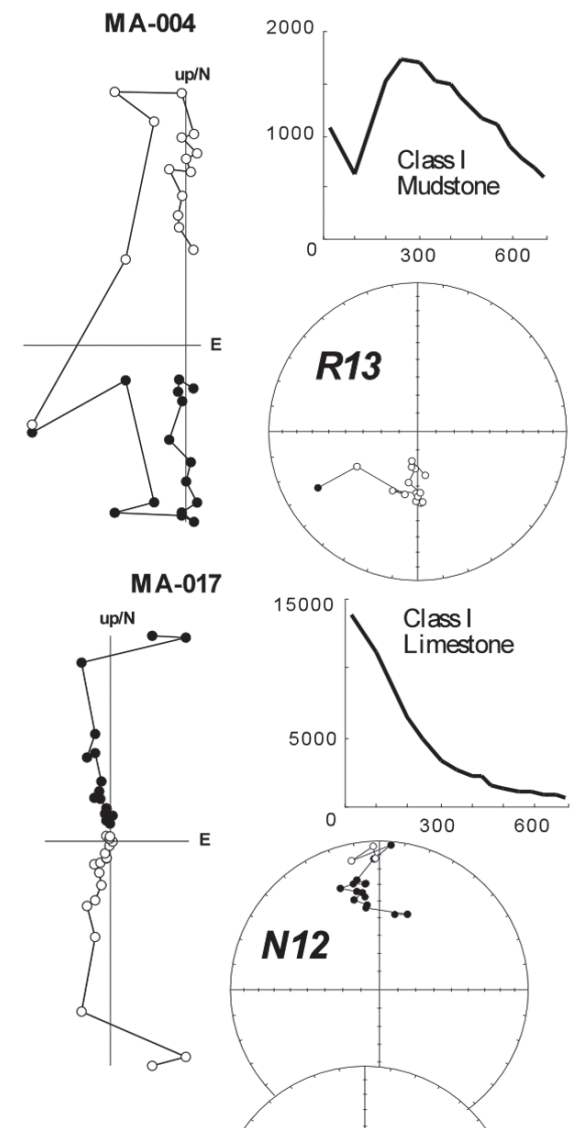

R15

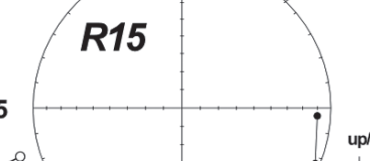

up/w

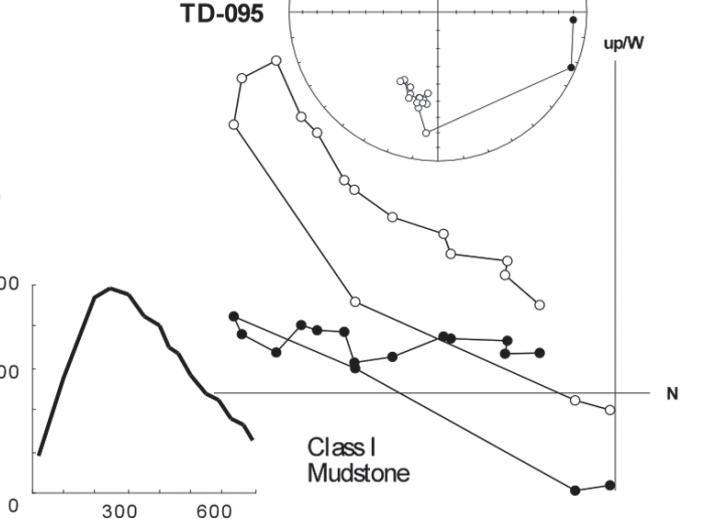

Fig. 6: Examples of thermal demagnetization in samples from the Amekchoud profile. For each sample it is displayed the orthogonal plot, the stereographic (equal area projection) and the thermal decay curve $\left({ }^{\circ} \mathrm{C}\right.$ ) of the total intensity of the magnetization (in $10^{-6} \mathrm{~A} / \mathrm{m}$ ). Five samples display normal polarity and four reverse polarity. Three distinctive samples come from the important N10 local chron. All samples are projected in a geographic coordinate system, although in most of them this orientation coincides with the paleogeographic reference frame (horizontal bedding).

PAM 207 is certainly less derived than the first Paraethomys entering Spain within chron C3An.2n, at about 6.2 Ma [35]. Therefore, the age of PAM 207 should be bracketed between 6.2 and 7.58+/-1.2 ma according to Paraethomys contents, although it may be perhaps placed near the lower boundary, taking into account the age of Afoud 6 (10.1 to 10.5 ma after magnetostratigraphy of Benammi et al. [17]) with similar Myocricetodon content.
The scarce literature about Neogene insectivores from Morocco does not permit a shorter bracketing of this age. The gap of determined species comprised between the Middle Miocene record of Lartetium dehmi from Beni-Mellal [36] and the Upper Pliocene records of Asoriculus, Crocidura and Suncus $[37,38]$, only permits to ascertain that the presence of an Oligosoricini crocidosoricinae is not in disagreement with the biochronological estimation provided by rodents. 


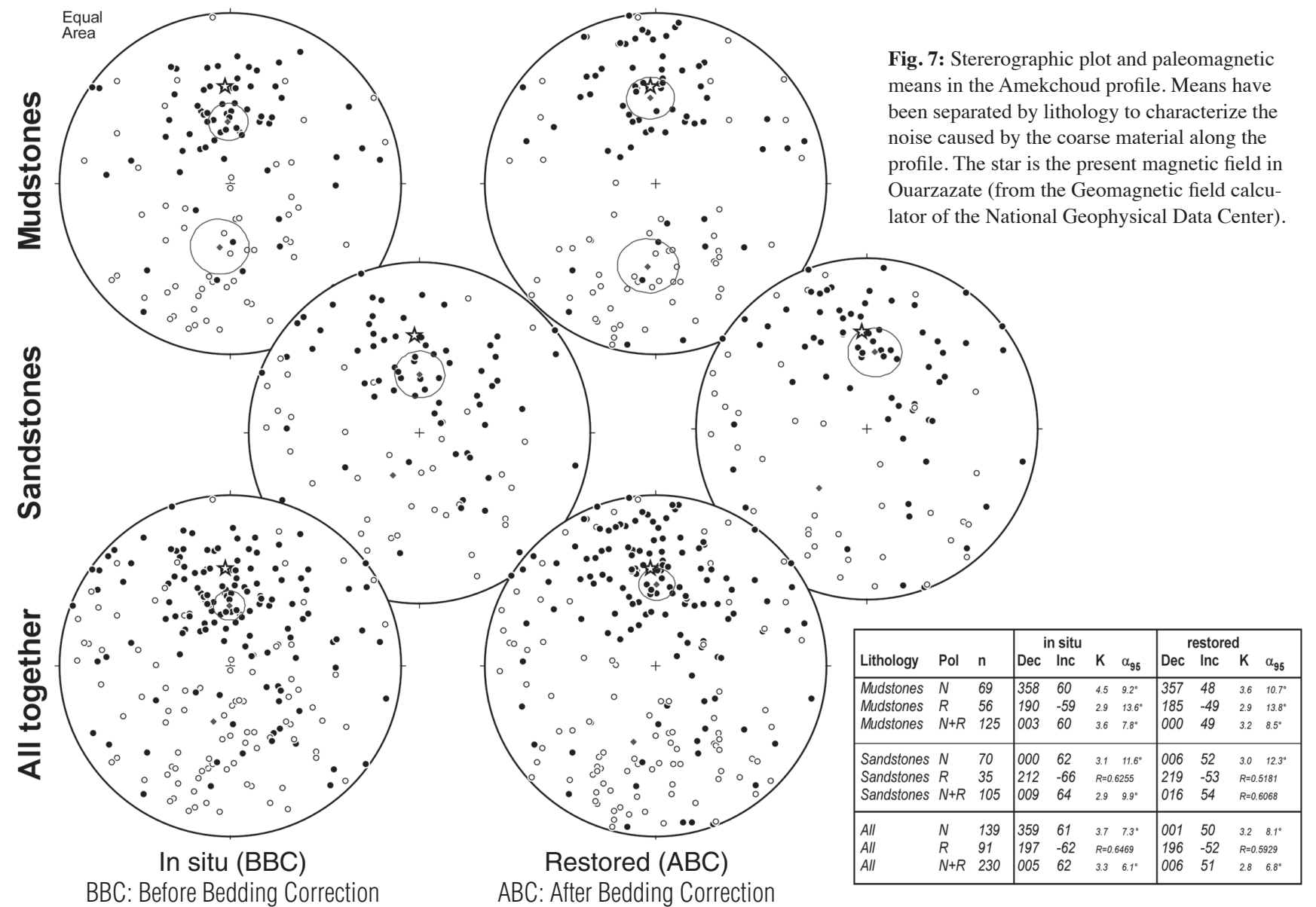

\section{Magnetostratigraphic data}

\subsection{Sampling and laboratory procedures}

Two magnetostratigraphic profiles have been analyzed to achieve a better chronology of the Ouarzazate basin infill. The Hadida profile consists in 465 meters along the Hadida formation. On the other hand, the Amekchoud profile is made of two sub sections, with 783 and 306 meters respectively, and spans along the Aït Ouglif and Aït Kandoula formations $[8,9,11]$. A total of 450 in situ-oriented cores (using a magnetic compass), were collected with water cooling drilling machine (348 in Amekchoud and 102 in Hadida). The lithology of the samples is as follows: 202 sandstones, 24 microconglomerates, 169 reddish mudstones, 42 limestones and 13 taken from laminated gypsum with shales, giving an average of one site (1 core) every three meters.

Standard specimens were measured in the Paleomagnetic Laboratory of the Earth Sciences Institute "Jaume Almera" (CSIC-University of Barcelona). Thermal stepwise demagnetization, was carried out to unravel the magnetic paleodirections, was performed with a $2 \mathrm{G}-\mathrm{DC}$ squid-magnetometer and a MMTD oven. After pilot demagnetizations, magnetic cleaning steps were set in $30^{\circ}-50^{\circ} \mathrm{C}$ intervals from room temperature up to $690^{\circ} \mathrm{C}$; around $14-15$ steps were measured in each sample.
Demagnetization orthogonal diagrams were interpreted using the PALDIR software package (Utrecht University). Characteristic remanent directions (ChRM) were fitted using principal component analysis (PCA, Kirschvink, [39]) and demagnetization circles analysis [40] at the sample scale. Fisher [41] statistics was used to calculate mean values at the section scale.

\subsection{Magnetic Components}

Initial susceptibility ranges between weakly diamagnetic $\left(-10 \cdot 10^{-6}\right.$ S.I.) in some whitish limestone levels and $447 \cdot 10^{-6}$ S.I. in the clay-rich reddish levels, although $90 \%$ of the samples span between 50 and $200 \cdot 10^{-6}$ S.I. The natural remanent magnetization displays moderate high values starting at $7 \cdot 10^{-6}$ $\mathrm{A} / \mathrm{m}$ in limestone levels, and reaching up to $\sim 40 \cdot 10^{-3} \mathrm{~A} / \mathrm{m}$ in sandstones; the majority of samples fall within the 1 to $10 \cdot 10^{-3} \mathrm{~A} / \mathrm{m}$ interval (Fig. 5).

The visual inspection of orthogonal demagnetization diagrams (Fig. 6) allows the definition of two main magnetic components: 1 ) between $20^{\circ}$ and $250^{\circ} \mathrm{C}$ : a recent magnetic recording of the present geomagnetic field often influenced by the drilling direction, 2) an intermediate temperature component (up to $400-500^{\circ} \mathrm{C}$ ) usually detected in limestone's and represents about $10 \%$ of the total dataset. The absence of further reliable information and the unblocking temperatures 


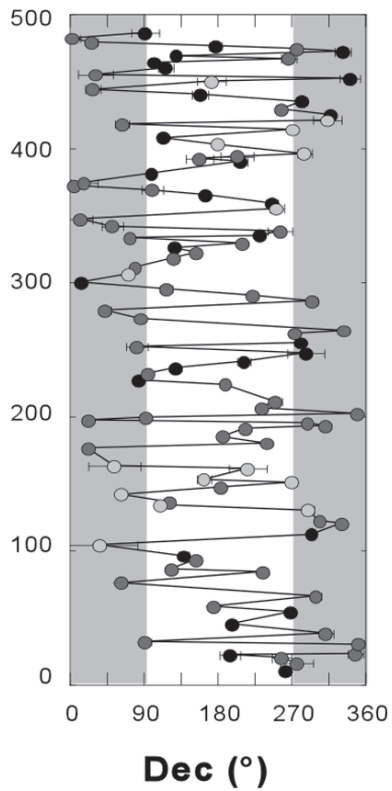

\section{HADIDA SECTION}
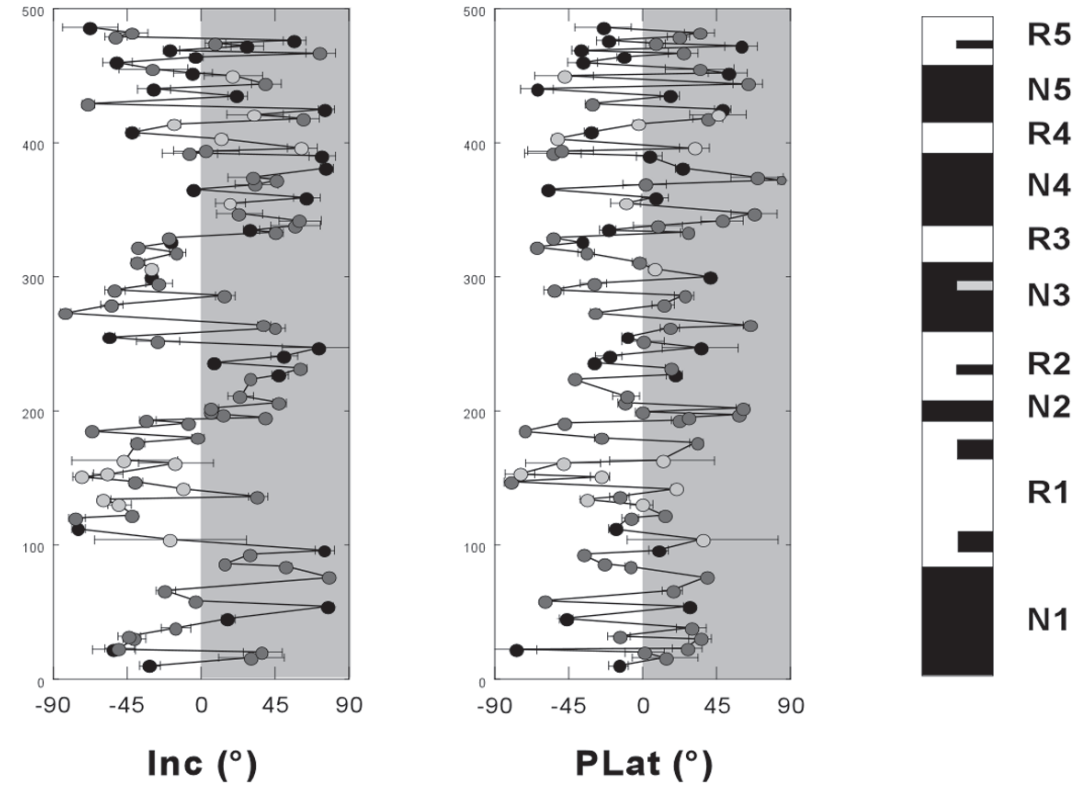

Fig. 8: Local magnetic polarity sequences of the Hadida section. Individual magnetic declination, inclination and corresponding paleolatitude (error bars represent the MAD of Kirschvink, 1980) are shown together with the stratigraphic profile. Black, grey, and whitish dots correspond to the sample quality type (classes I, II and III respectively).

suggest magnetite as the main carrier of these directions. 3) A high temperature and hard component $\left(250-680^{\circ}\right)$ associated to sandstones and reddish mudstones occur in $\approx 90 \%$ of the data and seem to be carried by hematite. Both, the intermediate and the high temperature components, show two polarities and meridian directions.

A typical scattering from terrestrial clastic series $[42,43,44,45]$ is found in the paleomagnetic signal at the sample scale. This is responsible for the apparent equatorial VGP latitudes recorded in some samples and can be caused by, 1) the differential delaying in the final blocking of the magnetization for different grain-sizes in the same rock. 2) Inclination error caused by the sedimentary load. 3) Overlapping of temperature spectrum of primary and presentfield directions at low-intermediate temperatures, which unlikely affects the primary polarity.

The Hadida profile is strongly influenced by these problems ( $\approx 50 \%$ of ambiguous paleolatitudes; VGP Lat $<30^{\circ}$ or $>-30^{\circ}$ ) and has been taken with caution to constrain the age of the base of the Ouarzazate Basin, nevertheless the presence of the Aznag fossil locality [24] in the base of the sequence is a good anchor point for this profile. In contrast the Amekchoud profile only displays $25 \%$ of ambiguous data (usually belonged to classes II or III) and can be used to build a feasible local polarity sequence.

The paleomagnetic directions fitted with the PCA method [39] have been classified in three distinct groups (Fig. 6): class I samples, where the direction points to the origin, the polarity is clear and the maximum angular deviation is below $10^{\circ}$, class II samples, which display less quality but unambiguously define the magnetic polarity of the magnetic field, and class III samples with doubtful polarities that were not used.

Although no significant fold test can be performed in the data set due to the very small dipping attitudes along the Amekchoud profile, the occurrence of two polarities with pseudo-antiparallel means (Fig. 7) $(\mathrm{N}=357,48$ [n: 69; a95: $\left.10.7^{\circ} ; \mathrm{k}: 3.6\right] ; \mathrm{R}=185,-49$ [n: 56 ; a95: $13.8^{\circ}, \mathrm{k}: 2.9$ only class I samples from mudstones) as well as the constant definition intervals allows us to be confident about the primary acquisition of the magnetic field. Moreover the dataset, in geographic coordinate system $\left(\mathrm{N}=358,60\right.$ [n: 69; $\left.\mathrm{a} 95: 9.2^{\circ} ; \mathrm{k}: 4.5\right] ; \mathrm{R}=$ 190,-59 [n: 56 ; a95: $\left.13.6^{\circ}, \mathrm{k}: 2.9\right)$, significantly differ from the present day magnetic field in Morocco $(357,42)$. On the other hand, and despite of the local scattering, the detected mean directions do not display any significant rotation when compared with the expected declination in northern Africa during the studied time span [46]. Future data coming from more suitable lithologies should confirm this observation.

\subsection{Magnetic polarity and correlation with GPTS}

Several polarity changes were found along the two studied sections (Fig. . 8 and 9). The following criteria have been considered to define the local sequence of magnetozones: 1) only class I and II directions were considered, 2) three or more sites are needed per zone, and 3) if only three sites are to define the magnetozone, at least one site should belong to class I.

Following these criteria, the Hadida section has to be taken with caution for a detailed correlation with the GPTS, since only $25 \%$ of the samples belong to class I and II, and 

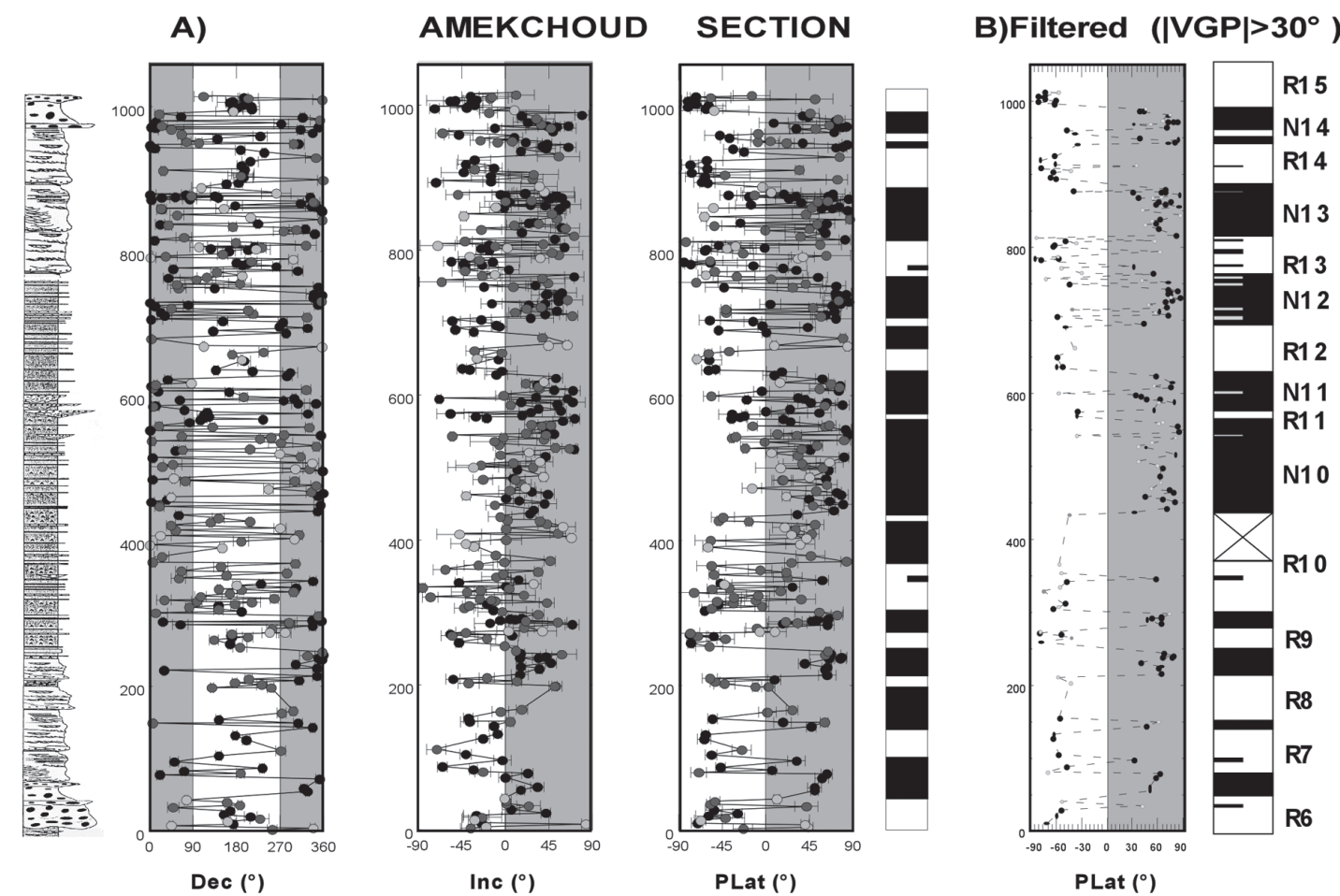

C)Only Mudstones

Fig. 9: Local magnetic polarity sequences of the Amekchoud section. A) Individual magnetic declination, inclination and corresponding paleolatitude (error bars represent the MAD of Kirschvink, 1980) are shown together with the stratigraphic profile. Black, grey, and whitish dots correspond to the sample quality type (classes I, II and III respectively). B) Paleolatitude filtered of low quality data: selecting only class I and II, and removing equatorial VGP's. C) Local magnetic sequence from "fine-material” (reddish mudstones and siltstones).

most local magnetozones are defined by few samples (Fig. 8); this difficulty should be considered in future studies of the Hadida formation geochronology.

On the other hand, the Amekchoud section of the Aït Ouglif and Aït Kandoula formations, which actually form the bulk of the Ouarzazate basin, yielded better results, where more than two thirds of the samples are reliable to define a polarity. This, together with the larger density and length of the profile, allows a better definition of the local magnetozone pattern (Fig. 9). When attempting to correlate with the GPTS, we have reduced noise by removing the equatorial VGPs $\left(<\mid 30^{\circ} \mathrm{I}\right)$ from the local sequence (Fig. 9b and 10). It is worth mentioning that most equatorial data had not been considered for the local zone definition in figures $9 \mathrm{~b}$ and 10 since they generally $(>70 \%)$ belonged to class II or III. This filtered local sequence of polarity fits almost perfectly when it is compared to the polarity column exclusively built with the more stable and reliable data from the reddish mudstones. Except for N7, R8 and R11 zones, where less than three sites define the polarity, the remaining magnetozones are characterized by a significant number of sites (between 6 and 34). N10 plus N11 represent the longest and best-defined magnetozone in the entire profile and is a significant anchor point for correlation.

Chron C5n is undoubtedly present and most probably can be correlated to the longest normal local zone N10-N11, characterized by more than 40 reliable samples (classes I and II) along two hundred meters of sequence (Fig. 10); accordingly, R10 are correlated to C5r. Within this assumption, the pattern of N8, R9 and N9 would correlate to C5An. The R8 magnetozone in our section would correspond to chron C5Ar, while N7 and R7 are correlated to C5AAn and C5Aar respectively. Therefore the lower part of Amekchoud profile could be placed in chron C5ABr. Consequently, the age of the base of Ait Ouglif formation in the Amekchoud section is upper Langhian. In the upper part of this profile the correlation has the anchor point of the fossil level PAM 207 (bracketed between 6.2 and 7.58+/-1.2).

As is discussed in the biostratigraphy chapter, the lower limit in age for PAM 207 corresponds to an indirect dating [33], so it must be taken with caution. PAM 207 is in the R13 magnetozone, so we correlate it to $\mathrm{C} 4 \mathrm{r}$ taking into account the biostratigraphic constraints. This correlation gives to our PAM 207 level an age of 8.1 to $8.75 \mathrm{ma}$, near the lower limit of the proposed bracket. This implies that the noisy R12 and N12 local zones correspond to the entire chron C4A. In the uppermost part of the Amekchoud section, N13 may be correlated to $\mathrm{C} 4 \mathrm{n}$; $\mathrm{R} 14$ and $\mathrm{R} 15$ to $\mathrm{C} 3 \mathrm{Br}$ and $\mathrm{C} 3 \mathrm{Ar}$ (Fig. 10). The resulting average accumulation rate for whole Amekchoud section is of about $15 \mathrm{~cm} / \mathrm{ka}$.

In summary, our proposed correlation suggests that the Ait Ouglif formation starts in the upper Langhian and the Ait Kandoula formation ends in the lower Messinian, with the limit between Aït Ibrirn and Aït Seddrat members in the upper Tortonian in the Ouarzazate basin. In the Amekchoud 


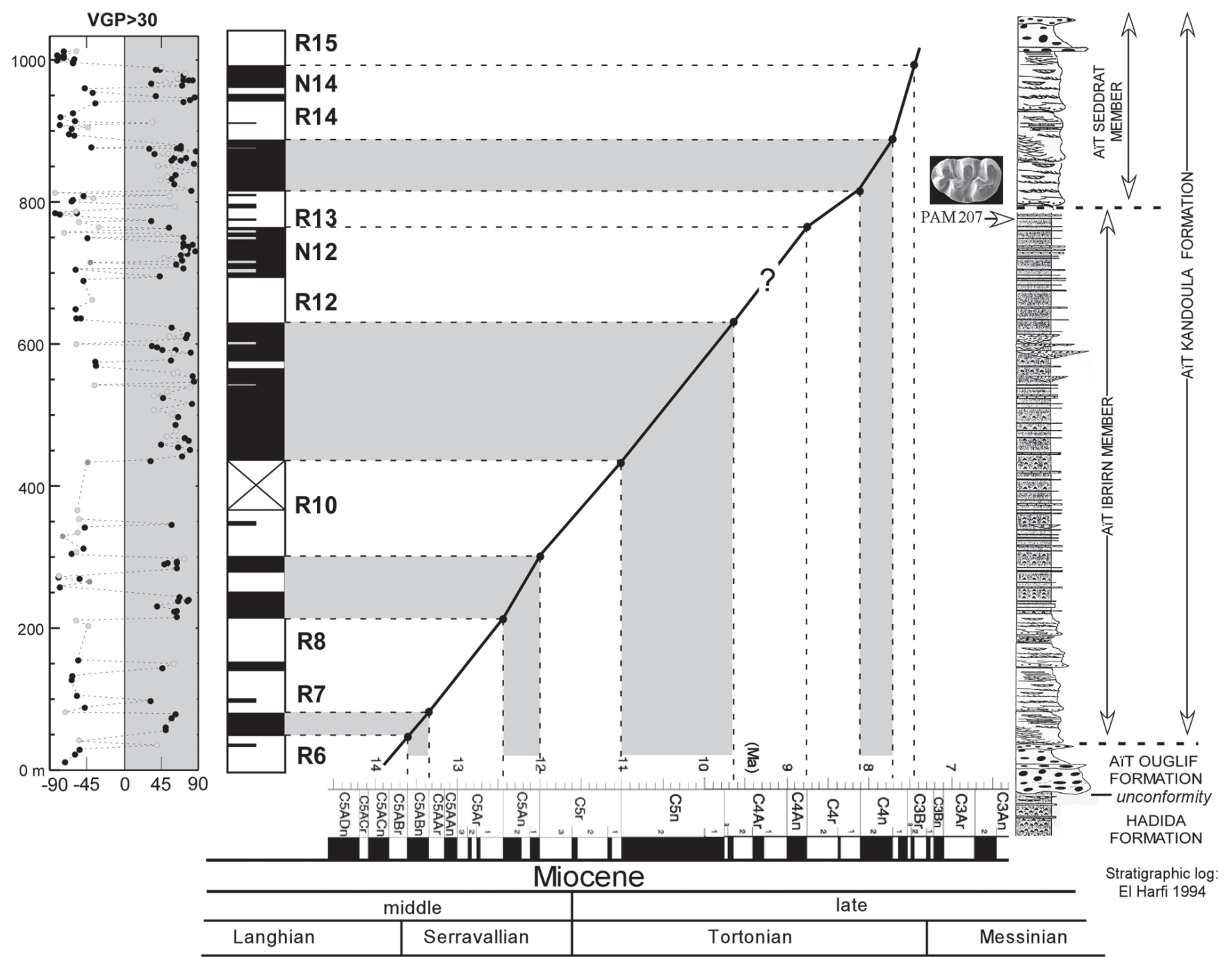

Fig. 10: Magnetostratigraphy and stratigraphic position of sampling sites of the Amekchoud section (filtered of low quality data). Indicated is the correlation of the profile to the geomagnetic polarity time scale of Cande and Kent [53]. PAM 207 marks the position of Amekchoud vertebrate layer. (Stratigraphic log modified from El Harfi [54]).

area, the Aï Ouglif formation is represented by only $9 \mathrm{~m}$ of conglomerate, but its thickness increases near the Sub-Atlas thrust belt, reaching locally up to $60 \mathrm{~m}[8,11]$. This formation has onlapping geometry; consequently the age lower limit of Aït Ouglif formation remains imprecise. Nevertheless, extending the sedimentation rates of the correlation down to the maximum observed thickness, this lower limit remains in Langhian times.

In spite of the low quality of the paleomagnetic record of the Hadida section, the lower $200 \mathrm{~m}$ (with a simple pattern of magnetozones; N1 and R1), coupled with the biostratigraphic constraints at the base, allow to make some inferences about the age of the Hadida formation. The Aznag fossil locality (Fig. 2A), located in the marine beds immediately under the Hadida formation, was dated as belonging to the P11 foraminiferal zone (upper part of Chron C20n and lowest part of C20n) [24]. Hence, the long N1 and R1 magnetozones in the profile may correspond to the mid-late Lutetian C20n $-\mathrm{C} 18 \mathrm{r}$ chrons (Fig. 8) giving an accumulation rate for this lower
$2 / 5$ of the formation of 7 to $10 \mathrm{~cm} / \mathrm{ka}$. From there upwards we cannot define an unambiguous correlation for the rest of the profile, but if we extrapolate the observed accumulation rates as "best-fit accumulation rate-dependent" of Talling and Burbank [47], we may conclude that the rest of the Hadida formation still belongs to the Eocene.

\section{Tectonic implications}

Combination of published paleontological data [24] and our magnetostratigraphic correlation indicate that the first alluvial influx from the High Atlas took place in mid Lutetian times ( 42-44 Ma, chron C20n), marked by the transition of Eocene marine limestones to Hadida/Aït Arbi continental shales, sandstones and conglomerates (Fig. 11). According to the published age of the limestone formation, platform marine sedimentation occurred at an average accumulation rate of $0.7-2 \mathrm{~cm} / \mathrm{ka}$, while with our tentative magnetostratigraphic correlation we obtain 


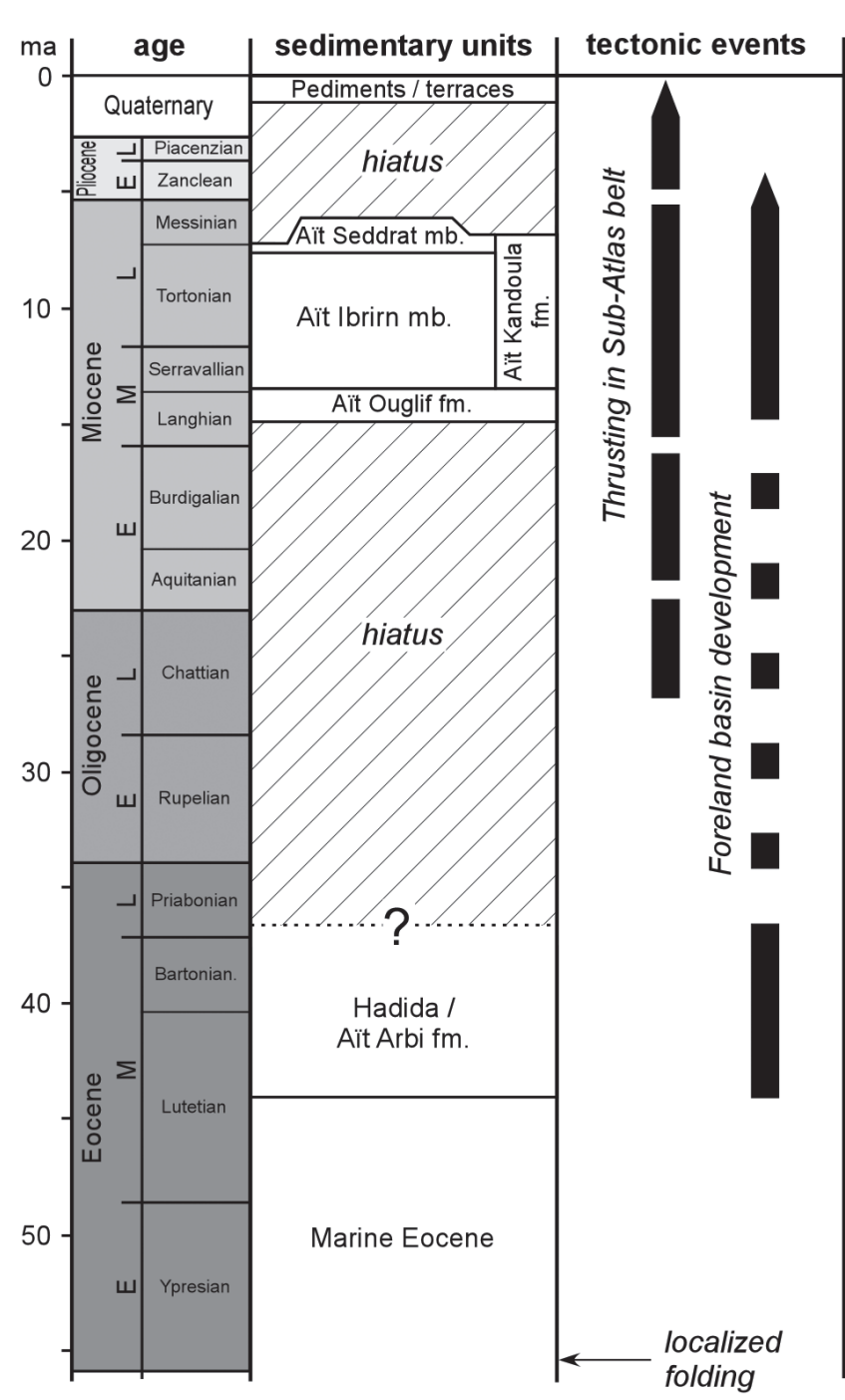

Fig. 11: Chronologic summary of the age of the synsedimentary formations (Hadida fm, Aït Ouglif fm. And Aït Kandoula fm.) in Ouarzazate basin, and distribution of the main tectonic events in the High Atlas domain.

increased rate of 7-10 cm/ka for the Hadida terrestrial formation. We do not favor an interpretation of the marine deposits as representatives of an early foreland basin stage, because of their reduced sedimentation rate and their present-day distribution in the interior of the High and Middle Atlas [48]. In agreement with El Harfi et al. [11], we interpret the Hadida/ Ait Arbi formations as the first foreland basin in front of the southern High Atlas, thus installed some 42-44 Ma ago. It is worth noting that foreland basin development coincided with marine to continental transition: in addition to an increased terrigenous influx and progradation, and to the effect of an eustatic sea-level fall during the late Lutetian [49], we may speculate that the regression in the area is largely due to mantle-related regional uplift in the whole Atlas domain, which is suggested by the coincidence with the end of the first pulse of alkaline magmatism occurring 40-45 ma ago. A nearly equilibrated competition between buoyant and thrust loads prevented the maintenance of marine conditions in the foreland basin.
According to the relative chronology of deformation proposed by Tesón and Teixell [13], thrusting began in the Sub-Atlas Zone some time between the end of sedimentation of the Hadida formation (Eocene-Oligocene boundary) and the Aït Ouglif conglomerate (late Langhian- early Serravallian). The large hiatus produced during this interval (20-25 Ma) prevents precising the onset of thrusting, but the amount of shortening recorded (70\% of the total measured from balanced sections in Tesón and Teixell [13]) suggests it might have started in the Oligocene.

On the other hand, the reason for this long lasting and widespread sedimentary gap remains difficult to explain. El Harfi et al. [10] suggested that it is indicative of a period of tectonic quiescence. However, the unconformable nature of the Ait Ouglif formation on well-characterized folds and thrusts [13] indicates that thrust loads should have been significant at least during part of this period of no sedimentary record. In addition, the hiatus largely coincides with a gap in the Atlas alkaline magmatism, which was not resumed until 15 ma ago. We suggest that during the late Eocene, at the end of the Hadida formation, the area reached a critical high elevation as a delayed response to the lithospheric thinning process recorded by the magmatism few millions years older. We cannot objectively tell whether the Atlas entered in a period of tectonic quiescence, because the Eocene deformation structures themselves have never been sorted out. From this time, the products of erosion from the growing Atlas Mountains and proximal Ouarzazate basin bypassed the foreland, which was probably externally drained since the marine stages of the early Paleogene. An accentuation effect of the climatic changes at the Eocene-Oligocene transition (with global cooling and sea level fall $[50,51]$ ) cannot be discarded.

According to our best fit correlation, the south Atlas foreland trapped sediments again, allowing the accumulation of the Aït Ouglif and Ait Kandoula formations from Langhian to Messinian times. During this interval the Ouarzazate basin became internally drained [9] and received the most important influx of sediments. El Harfi et al. [11] suggest but do not demonstrate that this indicates a period of renewed tectonic activity, whereas Missenard et al. [5] follow Frizon de Lamotte et al. [12] in considering it within a period of tectonic quiescence attributing the terrigenous input to the mantle-related thermal doming. However, on the basis of geometrical features displayed in detailed geological cross-sections, Tesón and Teixell [13] argue that the Ait Kandoula sedimentation does mark a stage of generalized thrusting in the Sub-Atlas belt, and that thrust loading was effective in creating a net subsiding basin at Ouarzazate.

In the Pliocene, the sedimentary record is again interrupted in the Ouarzazate basin; no sediments of this age are preserved in front of the thrust sheets. The only sediments of probable Pliocene age in the southern Atlas region are the lacustrine deposits of the hamadas, name that designates limestone tablelands that occur several hundreds kilometers to the ESE of the Ouarzazate basin, bordering the Anti-Atlas chain in southern Morocco and Algeria [52]. The propagation wave of the mantle-related uplift reached the Hamada area in late Pliocene times as discussed by Babault et al. [6]. 


\section{Conclusions}

New magnetostratigraphic and paleontological data from the Ouarzazate basin and flanking thrust belt provide constraints about the age of the terrestrial synorogenic successions of the southern foreland of the High Atlas Mountains. Magnetic stratigraphy, anchored by dated marine sediments just underneath, suggests a mid Lutetian age for the onset of foreland basin deposits; the end of the Hadida sedimentation is less constrained, being probably still in the Eocene. The Aït Ouglif and Aït Kandoula syntectonic formations that form the bulk of the infill of the Ouarzazate foredeep are dated on the basis of magnetic stratigraphy and a new vertebrate fossil locality of late Miocene age. According to our correlation, these formations are comprised between the Langhian and the Messinian in the Ouarzazate basin, although in the Aiit Kandoula intramontane basin, north of Ouarzazate, the Ait Kandoula formation may reach the base of the Pliocene if we follow Benammi et al. [17].

Within this chronological frame, a long sedimentary hiatus around 20-25 Ma is defined between the Hadida and Aït Ouglif formations. On top of the Airt Kandoula formation

\section{References}

[1] Teixell A, Arboleya M-L, Julivert M, Charroud M. Tectonic shortening and topography in the central High Atlas (Morocco). Tectonics (2003); 22 doi:10.1029/2002TC001460

[2] Teixell A, Ayarza P, Zeyen H, Fernandez M, Arboleya ML. Effects of mantle upwelling in a compressional setting: the Atlas Mountains of Morocco. Terra Nova (2005); 17: 456-61.

[3] Ayarza P, Alvarez-Lobato F, Teixell A, et al. Crustal structure under the central High Atlas Mountains (Morocco) from geological and gravity data. Tectonophysics (2005); 400: 67-84.

[4] Zeyen H, Ayarza P, Fernandez M, Rimi A. Lithospheric structure under the western African-European plate boundary; a transect across the Atlas Mountains and the Gulf of Cadiz. Tectonics (2005); 24.

[5] Missenard Y, Zeyen H, de Lamotte DF, et al. Crustal versus asthenospheric origin of relief of the Atlas Mountains of Morocco. Journal of Geophysical Research-Solid Earth (2006); 111.

[6] Babault J, Teixell A, Arboleya M-L, Charroud M. A late Cenozoic age for the long-wavelength surface uplift of the Atlas Mountains of Morocco. Terranova (2008); 20 (2) 102-07.

[7] Laville E, Lesage JL, Seguret M. Géométrie et cinématique (dynamique) de la tectonique sur le versant sud du Haut Atlas marocain. Aperçu sur les tectoniques hercyniennes et tardi-hercyniennes. Bulletin de la Société Géologique de France (1977); 7: 527-39.

[8] Fraissinet C, Zouine EM, Morel J-L, Poisson A, Andrieux J, FaureMuret A. Structural evolution of the southern and northern central High Atlas in Paleogene and Mio-Pliocene times. Lecture Notes in Earth Sciences (1988); 15: 273-91.

[9] Görler K, Helmdach F-F, Gaemers P, et al. The uplift of the central High Atlas as deduced from Neogene continental sediments of the Ouarzazate Province, Morocco. Lecture Notes in Earth Sciences (1988); 15: 361-404. another interruption of the sedimentary record is observed below quaternary pediments and terraces. While the precise causes for the first interruption remain speculative, the mantlerelated uplift documented by Babault et al. [6] after Miocene times may account for the second hiatus and the end of the Tertiary sedimentation in the Ouarzazate basin, which became externally drained some time during this period.

The main thrusting episode leading the generation of the SubAtlas external fold-and-thrust belt begins during the Oligocene and extends up to recent times. The initiation of orogeny in the High Atlas hinterland is placed in mid Eocene times (Lutetian), as recorded by the terrigenous influx and subsidence increase of the Hadida and the equivalent Ait Arbi formations.

\section{Acknowledgements}

This work has been supported by MEC projects CGL200524158-E, CGL2006-07226 and CGL2006-4548, the Consolider-Ingenio 2010 project CDS2006-00041, and AECI grant A/2921/05. We thank J. Babault and M.L. Arboleya for scientific discussion and assistance in the sampling campaigns.

[10] El Harfi A, Lang J, Salomon J. Le Remplissage continental cénozoique du bassin d'avant-pays de Ouarzazate; implications sur l'évolution géodynamique du Haut-Atlas central (Maroc). Comptes Rendus de l'Académie des Sciences, Série II Sciences de la Terre et des Planètes (1996); 323: 623-30.

[11] El Harfi A, Lang J, Salomon J, Chellai EH. Cenozoic sedimentary dynamics of the Ouarzazate foreland basin (central High Atlas Mountains, Morocco). International Journal of Earth Sciences (2001); 90: 393-411.

[12] Frizon de Lamotte D, Saint Bezar B, Bracène R. The two main steps of the atlas building and geodynamics of the Western Mediterranean. Tectonics (2000); 19: 740-61.

[13] Tesón E, Teixell A. Sequence of thrusting and syntectonic sedimentation in the eastern Sub-Atlas thrust belt (Dades and Mgoun valleys, Morocco). International Journal of Earth Sciences (2008); 97: 103-13.

[14] Couvreur G. Etagement de formes et neotectonique sur le versant sud du Haut Atlas. Revue de Geomorphologie Dynamique (1973); 22: 109-24.

[15] Sebrier M, Siame L, Zouine EM, Winter T, Missenard Y, Leturmy P. Active tectonics in the Moroccan High Atlas. Comptes Rendus Géoscience (2006); 338: 65-79.

[16] Arboleya M-L, Babault J, Owen LA, Teixell A, Finkel RC. Timing and nature of Quaternary fluvial incision in the Ouarzazate foreland basin, Morocco. Journal of the Geological Society, London (2008); 165: 1059-73.

[17] Benammi M, Calvo M, Prevot M, Jaeger J-J. Magnetostratigraphy and paleontology of Ait Kandoula Basin (High Atlas, Morocco) and the African-European late Miocene terrestrial fauna exchanges. Earth and Planetary Science Letters (1996); 145: 15-29. 
[18] Benammi M, Jaeger JJ. Magnetostratigraphy and palaeontology of the continental Middle Miocene of the Aït Kandoula Basin, Morocco. Journal of African Earth Sciences (2001); 33: 335-48.

[19] Mattauer M, Tapponier P, Proust F. Sur les mécanismes de formation des chaines intracontinentales. L'exemple des chaines atlasiques du Maroc. Bulletin de la Société Géologique de France (1977); 7, t.19: 521-26.

[20] Jacobshagen V, Brede R, Hauptmann M, Heinitz W, Zylka R. Structure and post-Palaeozoic evolution of the central High Atlas. Lecture Notes in Earth Sciences (1988); 15: 245-71.

[21] Arboleya ML, Teixell A, Julivert M, Charroud M. A structural transect through the High and Middle Atlas of Morocco. Journal of African Earth Sciences (2004); 39: 319-27.

[22] Gauthier H. Contribution à l'étude géologique des formations postliasiques des bassins du Dades et du haut Todra (Maroc meridional). Notes et Mémoires du Service Géologique (Rabat) (1957); 119: $1-137$

[23] Marzoqi M, Pascal A. Séquences de dépôts et tectono-eustatisme àç la limite cretace/tertiaire sur la marge sud-tethysienne (Atlas de Marrakech et bassin de Ouarzazate, Maroc). Newsletters on Stratigraphy (2000); 38: 57-80.

[24] Tabuce R, Adnet S, Cappetta H, Noubhani A, Quillevere F. Aznag (Ouarzazate basin, Morocco), a new African middle Eocene (Lutetian) vertebrate-bearing locality with selachians and mammals. Bulletin de la Société Géologique de France (2005); 176: 381-400.

[25] Froitzheim N, Stets J, Wurster P. Aspects of western High Atlas tectonics. Lecture Notes in Earth Sciences (1988); 15: 219-44.

[26] Herbig H-G, Trappe J. Stratigraphy of the Subatlas Group (Maastrichtian-Middle Eocene, Morocco). Newsletters on Stratigraphy (1994); 30: 125-65.

[27] Jaeger JJ. Les Rongeurs du Miocène moyen et supérieur du Maghreb (Rodents from the middle and upper Miocene of Maghreb). Palaeovertebrata (1977); 8: 1-166.

[28] Jaeger JJ, Michaux J, Thaler L. Présence d'un rongeur muride nouveau, Paraethomys miocaenicus nov. sp. dans le Turolien supérieur du Maroc et d'Espagne; implications paleogeographiques. Comptes Rendus Hebdomadaires des Séances de l'Académie des Sciences, Serie D: Sciences Naturelles (1975); 280: 1673-76.

[29] Benammi M. Decouverte de deux nouvelles especes du genre Myocricetodon dans le Miocene superieur du bassin d'Ait Kandoula (Maroc). Comptes Rendus de l'Académie des Sciences, Série II Sciences de la Terre et des Planetes (2001); 333: 187-93.

[30] Coiffait B. Contribution des rongeurs du Néogene d'Algerie a la Biochronologie mammalienne d'Afrique nord-occidentale. Ph D Thesis University of Nancy (1991): 1-389.

[31] Furió M, Santos-Cubedo A, Minwer-Barakat R, Agustí J. Evolutionary history of the African soricid Myosorex (Insectivora, Mammalia) out of Africa. Journal of Vertebrate Paleontology (2007); 27: 1018-32.

[32] Coiffait B, Coiffait PE, Jaeger JJ. Decouverte en Afrique du Nord des genres Stephanomys et Castillomys (Muridae) dans un nouveau gisement de microvertebres neogenes d'Algerie orientale; Argoub Kemellal. Proceedings of the Koninklijke Nederlandse Akademie van Wetenschappen Series B: Palaeontology, Geology, Physics, Chemistry, Anthropology (1985); 88: 167-83.

[33] Choubert G, Charlot R, Faure-Muret A, et al. Note preliminaire sur le volcanisme messinien-'pontien' au Maroc. Comptes Rendus
Hebdomadaires des Séances de l'Académie des Sciences, Série D: Sciences Naturelles (1968); 266: 197-99.

[34] Harland WB, Cox AV, Llewellyn PG, Pickton CAG, Smith AG, Walters R. A geologic time scale. Cambridge Univ. Press, Cambridge, (1982), 263 p.

[35] Agusti J, Garces M, Krijgsman W. Evidence for African-Iberian exchanges during the Messinian in the Spanish mammalian record. Palaeogeography, Palaeoclimatology, Palaeoecology (2006); 238: $5-14$.

[36] Lavocat R. Le gisement de vertébrés miocènes de Beni Mellal (Maroc). Étude systématique de la faune de mammifères et conclusions générales. Notes et Mémoires du Service Géologique du Maroc (1961); 155: 1-177.

[37] Rzebik-Kowalska B. Soricidae (Mammalia, Insectivora) from the Plio-Pleistocene and middle Quaternary of Morocco and Algeria. Folia Quaternaria (1988); 57: 51-90.

[38] Geraads D. Rongeurs et insectivores (Mammalia) du Pliocene final de Ahl Al Oughlam (Casablanca, Maroc). Geobios (1995); 28 : 99-115.

[39] Kirschvink JL. The least-squares line and plane and the analysis of palaeomagnetic data. Geophysical Journal of the Royal Astronomical Society (1980); 62: 699-718.

[40] Bailey RC, Halls HC. Estimate of confidence in paleomagnetic directions derived from mixed remagnetization circle and direct observational data. Journal of Geophysics = Zeitschrift fuer Geophysik (1984); 54: 174-82.

[41] Fisher RA. Dispersion on a sphere. Proceedings of the Royal Society of London, Series A (1953); 217: 295-305.

[42] Bentham P, Burbank DW. Chronology of Eocene foreland basin evolution along the western oblique margin of the South-Central Pyrenees. In: Friend PF, Dabrio CJ, eds. Tertiary basind of Spain: Cambridge University Press, (1996); 144-52.

[43] Kempf O, Matter A, Burbank DW, Mange M. Depositional and structural evolution of a foreland basin margin in a magnetostratigraphic framework; the eastern Swiss Molasse Basin. Geologische Rundschau = International Journal of Earth Sciences (1998); 88: 253-75.

[44] Brozovic N, Burbank DW. Dynamic fluvial systems and gravel progradation in the Himalayan foreland. Geological Society of America Bulletin (2000); 112: 394-412.

[45] Homke S, Verges J, Garces M, Emami H, Karpuz R. Magnetostratigraphy of Miocene-Pliocene Zagros foreland deposits in the front of the Push-e Kush Arc (Lurestan Province, Iran). Earth and Planetary Science Letters (2004); 225: 397-410.

[46] Besse J, Courtillot V. Apparent and true polar wander and the geometry of the geomagnetic field over the last 200 Myr. Journal of Geophysical Research (2002); 107

[47] Talling PJ, Burbank DW. Assessment of uncertainties in magnetostratigraphic dating of sedimentary strata. Special Publication - Society of Economic Paleontologists and Mineralogists (1993); 49: 59-69.

[48] Trappe J. Microfacies zonation and spatial evolution of a carbonate ramp: marginal Moroccan phosphate sea during the Paleogene. Geologische Rundschau (1992); 81: 105-126.

[49] Abreu VS, Anderson JB. Glacial eustasy during the Cenozoic; sequence stratigraphic implications. AAPG Bulletin (1998); 82 $1385-400$. 
[50] Zachos JC, Pagani M, Sloan L, Thomas E, Billups K. Trends, rhythms, and aberrations in global climate $65 \mathrm{Ma}$ to present. Science (2001); 292: 686-693.

[51] Miller KG, Kominz MA, Browning JV, Wrigth JD, Mountain GS, Katz ME, Sugarman PJ, Cramer BS, Christie-Blink N, Pekar SF. The phanerozoic record of global seal-level change. Science (2005); 310: 1293-1298.

[52] Lavocat R. Reconnaissance geologique dans les hammadas des confins algero-marocains du sud. Notes et Mémoires du Service Géologique (Rabat) (1954); 116: 1-122.
[53] Cande SC, Kent DV. Revised calibration of the geomagnetic polarity timescale for the Late Cretaceous and Cenozoic. Journal of Geophysical Research (1995); 100: 6093-95.

[54] El Harfi A. Dynamique sédimentaire des séries continentales tertiaries au Sud du Haut-Atlas central (bassins de Ouarzazate et Anzal, Maroc). Faciès et milieux de dépôts. Evolution diagénetique et pédogénétique. Thèse, Univ Bourgogne, Dijon, (1994); 1-314.Fig. re captions 
